\title{
Kinetics and mechanism of oxidation of GSH by cis-(diaqua)-bis-(ethylenediamine) Cobalt(III) ion
}

\author{
B. Mohanty ${ }^{1 *}$, J. Behera ${ }^{1}$, S. Acharya ${ }^{2}$, P. Mohanty ${ }^{1}$, A.K. Patnaik ${ }^{3}$ \\ ${ }^{1}$ Department of Chemistry, Utkal University, Bhubaneswar, 751004, Odisha, India \\ ${ }^{2}$ IMMT, Bhubaneswar, Odisha, India \\ ${ }^{3}$ Ravenshaw University, Cuttack, 753003, Odisha, India \\ *Corresponding author E-mail: omm.gayatri@gmail.com
}

\begin{abstract}
The kinetics of GSH oxidation to GSSG by cis-(diaqua)-bis-(ethylenediamine) cobalt(III) perchlorate was studied spectophotometrically under pseudo-first order condition using $10^{3}[\mathrm{Co}(\mathrm{III})]=5 \mathrm{~mol} \mathrm{dm}^{-3}, 2.5 \leq 10^{2}[\mathrm{GSH}] \leq 10.00 \mathrm{~mol} \mathrm{dm}^{-3}, 3.5 \leq \mathrm{pH} \leq 5.0,318 \mathrm{~K} \leq \mathrm{T} \leq 333 \mathrm{~K}$ at a fixed ionic strength $\mathrm{I}=0.3 \mathrm{~mol} \mathrm{dm}\left(\mathrm{NaClO}_{4}\right)$. The disappearance of [Co (III)] at $500 \mathrm{~nm}$ with time showed first-order kinetic trend. The first order dependence on $[\mathrm{GSH}]$ and $\mathrm{pH}$ was observed. Temperature dependence of the second order rate constant $\mathrm{k}_{2}^{\prime}=\mathrm{k}_{\mathrm{obs}} /[\mathrm{GSH}]$ were analysed for the $\mathrm{Co}(\mathrm{III})-\mathrm{OH}_{2}{ }^{3+}\left(\mathrm{k}_{1}\right)$ and $\mathrm{Co}(\mathrm{III})-\mathrm{OH}^{2+}\left(\mathrm{k}_{2}\right)$ reactivities. An outer-sphere complex formation between the Co(III) and GSH followed by one-electron transfer from GSH to Co(III) resulting the formation of Co(II) and GS ${ }^{\mathrm{x}}$ radical. The GS ${ }^{\mathrm{x}}$ radical undergoes fast dimerisation to GSSG. Activation parameters were calculated. These values favor the electron transfer reaction.
\end{abstract}

Keywords: Co (III) complex, GSH, GSSG, Spectrophotometer, Redox reaction.

\section{Introduction}

Glutathione (GSH) is a tripeptide containing three amino acids L-cysteine, L-glutamic acid and L-glycine with unusual peptide linkage between amine group of cysteine and carboxylic group of glutamate. The thiol group ( $\mathrm{SH})$ of cysteine serves as proton donor and is responsible for the biological activity of glutathione. It plays a fundamental role in numerous metabolic and biochemical reactions such as DNA synthesis and repair, protein synthesis, amino acid transport and enzyme activation.

Because of the importance of GSH, we are interested to study the kinetics of oxidation of GSH by biological active cobalt complex. Cobalt is an essential trace element for all organisms as the active center of co-enzyme called cobalamines. This includes vitamin $\mathrm{B}_{12}$ which is essential for mammals. A deficiency of cobalt leads to pernicious anaemia. Studies on the chemistry of electron transfer reaction of cobalt(III) complexes have received a sustained high level of attention from the scientific community for decades due to their relevance in various redox processes in biological system and act as promising agent for antitumor (Osinsky et al. 2003, Osinsky et al. 2004), anthelmintic (Behm et al. 1993), antiparasitic (Behm et al. 1995, Karaman et al. 1995), antibiotics (Ghirlanda et al. 1998), and antimicrobial activities (Srinivasan et al. 2005). Numerous studies have been performed, addressing the dependence of electron transfer on different environments including metalloproteins (Bernauer et al. 1999), vitamin $B_{12}$ (Wolak et al. 2003), liquids (Burel et al. 1999, Saik et al. 2004), micelles (Weidemaier et al. 1997, Travernier et al. 1998), vesicles (Gerasimov et al. 1988), and DNA (Srinivasan et al. 2005).

We report here redox reactions of GSH with Co (III) complex as oxidant and GSH as reductant. The product was isolated, identified and mechanism was proposed.

\section{Experimental}

\subsection{Material and methods}

Cis -(diaqua) - bis - (ethylenediamine) cobalt (III) perchlorate was prepared following the reported method (Basolo \& Pearson 1964, Krisnamurty 1972). It was recrystallised and dried. The solid complex was characterized by elemental analysis and spectroscopic methods. All other chemicals used were of AnalaR grade. Doubly distilled water was used to prepare all the solutions. The acid strength of the medium was maintained by addition of $\mathrm{HClO}_{4}$. The UV-Vis spectra of the complex showed the characteristic peaks at $380 \mathrm{~nm}\left(\varepsilon=65 \mathrm{dm}^{-3} \mathrm{~mol}^{-1} \mathrm{~cm}^{-1}\right)$ and 500 $\mathrm{nm}\left(\varepsilon=80 \mathrm{dm}^{-3} \mathrm{~mol}^{-1} \mathrm{~cm}^{-1}\right)$.

\subsection{Kinetic study}

Kinetics of oxidation of GSH by Co (III) complex in perchloric acid medium was studied from 318 to $333 \mathrm{~K}, \mathrm{I}=0.3 \mathrm{~mol} \mathrm{dm}^{-3}$ $\left(\mathrm{NaClO}_{4}\right)$. The kinetic measurements were carried out with a systronic 2202 UV-Vis spectrophotometer equipped with a thermostatic water bath for temperature control (accuracy = $0.1^{\circ} \mathrm{C}$ ). The progress of the reaction was monitored by following the decrease in absorbance at $500 \mathrm{~nm}$ "Fig. 1". The detail experimental procedure of kinetic study was reported in our published paper (Mohanty et al. 2011). The kinetics were studied under pseudo-first order conditions, where the substrate[GSH] varied from $2.5 \times 10^{-2} \mathrm{~mol} \mathrm{dm}^{-3}$ to $10.0 \times 10^{-2} \mathrm{~mol} \mathrm{dm}^{-3}$ and $\mathrm{pH}$ was varied from 3.5 to 5.0 and the $[\mathrm{Co}(\mathrm{III}) \mathrm{L}]$ complex is $5 \times 10^{-3} \mathrm{~mol}$ $\mathrm{dm}^{-3}$. The rate constants $\left(\mathrm{k}_{\mathrm{obs}}\right)$ were calculated from the slope of $\ln \left(\mathrm{A}_{\mathrm{t}}-\mathrm{A}_{\infty}\right)$ versus $\mathrm{t}(\mathrm{s})$ plots from the relationship using computer program. 
$\ln \left(A_{t}-A_{\infty}\right)=\ln \left(A_{0}-A_{\infty}\right)-k_{\text {obs }} . t$

Where $A_{0}, A_{t}, A_{\infty}$ denote optical density of the reaction mixture at zero time, time $t$ and at infinite time respectively. $\mathrm{A}_{\infty}$ was measured after completion of the reaction. The correlation coefficients of plots used to determine $k_{\mathrm{obs}}$ were found to be 0.99 in most of the cases.

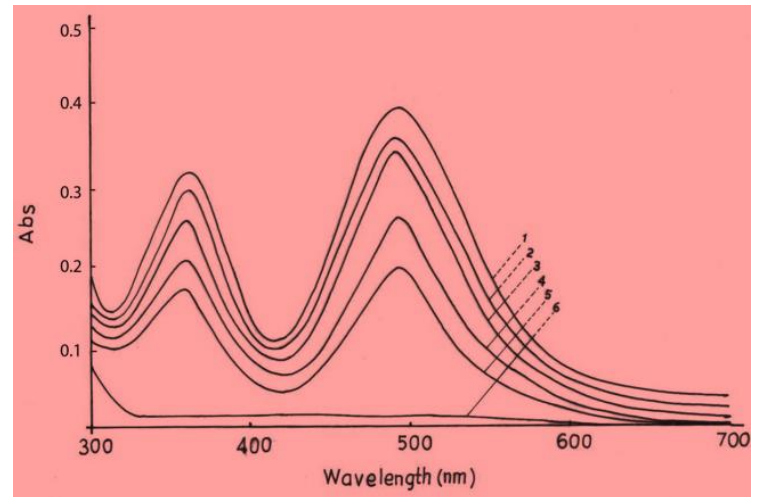

Fig. 1: UV-Vis spectral scan of GSH with $\mathrm{Co}$ (III) at $303 \mathrm{~K}, \mathrm{pH}=4.0$, Co (III) $=0.005 \mathrm{~mol} \mathrm{dm}^{-3}, \mathrm{I}=0.3 \mathrm{~mol} \mathrm{dm}^{-3}\left(\mathrm{NaClO}_{4}\right)$, (1) Immediate after mixing, curves $(2,3) \Delta t=5$ mins, curves $(4,5) \Delta t=10$ mins, $(6)$ after $24 \mathrm{hs}$

\section{Stoichiometry and characterization of the product}

The reaction mixture containing [substrate] and [Co (III) L] in ratio $1: 10, \mathrm{I}=0.3 \mathrm{~mol} \mathrm{dm}{ }^{-3}\left(\mathrm{NaClO}_{4}\right)$ were allowed to react till completion of the reaction. From the above stoichiometry study it was revealed that the reaction exhibited as 1:1 stoichiometry for GSH oxidation.

$2 \mathrm{Co}^{3+}+2 \mathrm{e}=2 \mathrm{Co}^{2+}$

$2 \mathrm{GSH}=\mathrm{GSSG}+2 \mathrm{H}^{+}+2 \mathrm{e}$

$2 \mathrm{Co}(\mathrm{III})+2 \mathrm{GSH}+2 \mathrm{OH}^{-}=2 \mathrm{Co}$ (II) $+\mathrm{GSSG}+2 \mathrm{H}_{2} \mathrm{O}$

To prepare the reaction product $[\mathrm{Co}$ (III) $\mathrm{L}]=0.05 \mathrm{~mol} \mathrm{dm}^{-3}$ was mixed with hot solution of $\left[\mathrm{HClO}_{4}\right]=0.005 \mathrm{~mol} \mathrm{dm}^{-3}$, then $\mathrm{pH}$ of the solution was adjusted to 4.5 (Sol-I). In a separate beaker $[\mathrm{GSH}]=0.05 \mathrm{~mol} \mathrm{dm}^{-3}$ was mixed with $\mathrm{NaClO}_{4}=0.3 \mathrm{~mol} \mathrm{dm}^{-3}$. Its $\mathrm{pH}$ was adjusted to 4.5 (Sol-II). Both the solutions (I and II) were mixed and evaporated in a thermostat at $60^{\circ} \mathrm{C}$ for $3 \mathrm{~h}$ till a pasty solution was formed. Then it was slowly dried in a desiccator. The yield of the product was nearly $70 \%$. The FTIR spectra of the dried product were recorded "Fig. 3" in a Perkin Elmer (UK) FTIR spectrophotometer using $\mathrm{KBr}$ pellet technique and it was compared with FTIR spectra of the substrate GSH "Fig. 2". Co (II) in the product was identified by Kitson method (Kitson 1950).

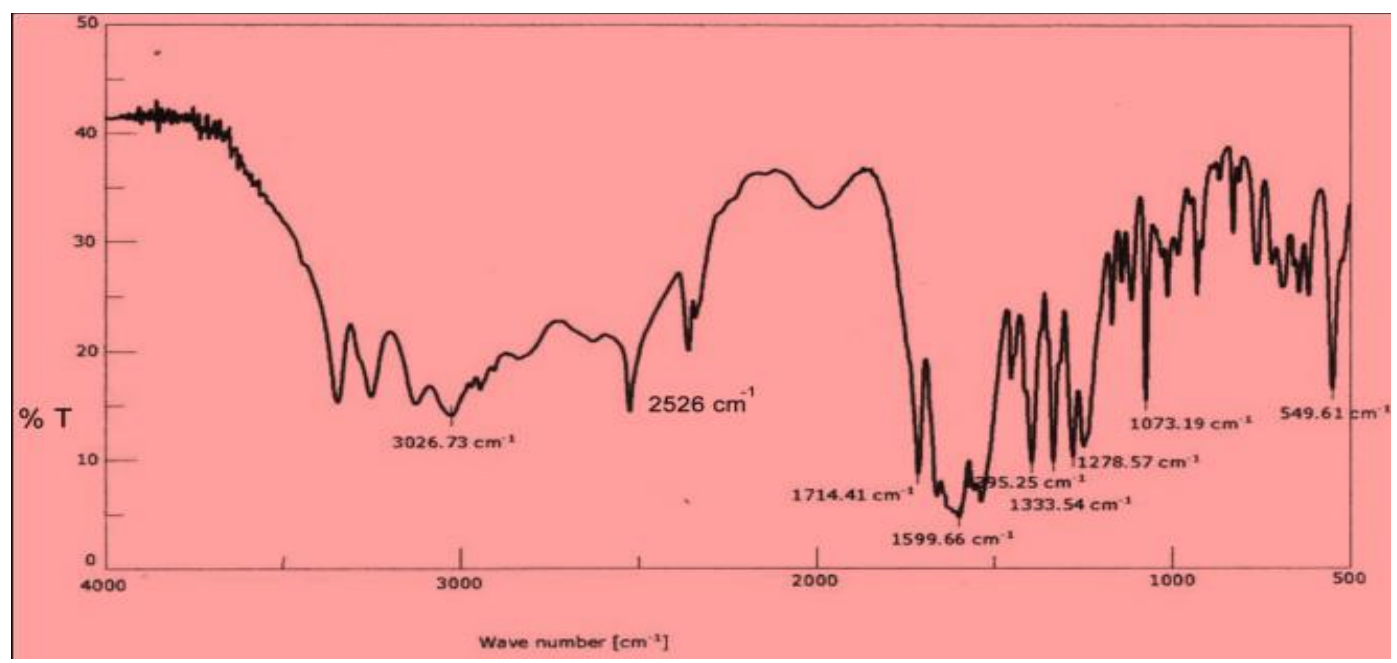

Fig. 2: FTIR spectra of pure GSH

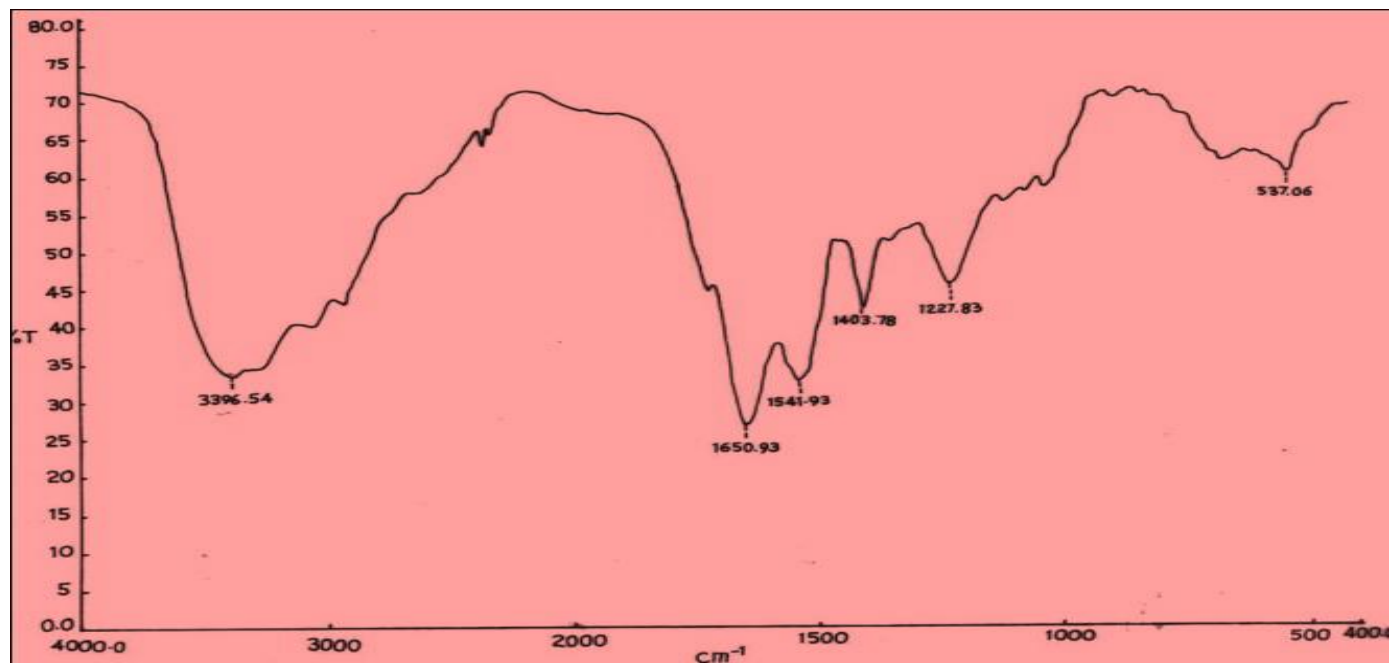

Fig. 3: FTIR spectra of oxidation product GSSG

"Fig. 3" showed a broad peak at $3396.54 \mathrm{~cm}^{-1}$ in the product may be assigned to $v_{\mathrm{N}-\mathrm{H}}\left(\mathrm{NH}_{3}^{+}\right)$as compared to $3252 \mathrm{~cm}^{-1}$ and 3026 $\mathrm{cm}^{-1}$ in GSH. The shifting to higher frequency was probably due to an association of water molecules with the product. The $\mathrm{NH}_{3}{ }^{+}$ bending bands and a strong absorption peak of carboxylate ion are mixed up and a broad band is observed at $1650.93 \mathrm{~cm}^{-1}$ in the product compared to $1600 \mathrm{~cm}^{-1}, 1538 \mathrm{~cm}^{-1}$ and $1395 \mathrm{~cm}^{-1}$ peak in GSH. The strong peaks at $1541.93 \mathrm{~cm}^{-1}, 1403.78 \mathrm{~cm}^{-1}, 1227.83$ $\mathrm{cm}^{-1}$ and $537.06 \mathrm{~cm}^{-1}$ in the product corresponds to $1599.66 \mathrm{~cm}^{-1}$, $1383.54 \mathrm{~cm}^{-1}, 1278.57 \mathrm{~cm}^{-1}$ and $549.61 \mathrm{~cm}^{-1}$ in GSH is due to the 
free $\mathrm{NH}_{2}$ twisting and rocking (Nakamoto $5^{\text {th }} \mathrm{Edn}$ ). The weak band at $2526 \mathrm{~cm}^{-1}$ in GSH due to S-H stretching is absent in the product suggesting the dimerisation of GSH to GSSG having S-S linkage. The product was isolated as GSSG. [(2S)-2-amino-5[[(2R)-3-[(2R)-2-[[(4S)-4-amino-5-hydroxy-5-

oxopentanoyl]amino]-3-[carboxymethylamino)-3-

oxopropyl]disulfanyl-1-(carboxymethylamino)-1-oxopropan-2-

yl]-5-oxopentanoic acid]. The structure of substrate (GSH) and product (GSSG) was shown as<smiles>N[C@@H](CCC(=O)N[C@@H](CS)C(=O)NCC(=O)O)C(=O)O</smiles><smiles>N[C@@H](CCC(=O)N[C@@H](CSSC[C@H](NC(=O)CC[C@H](N)C(=O)O)C(=O)NCC(=O)O)C(=O)NCC(=O)O)C(=O)O</smiles>

\section{Results}

All kinetic runs were performed under pseudo-first order conditions.

\subsection{Effect of $[\mathrm{GSH}]$ on reaction rate}

With the varying concentration of $[\mathrm{GSH}]=2.5 \times 10^{-2}$ to $10.0 \mathrm{x}$ $10^{-2} \mathrm{~mol} \mathrm{dm}^{-3}, 10^{4} k_{\text {obs }}\left(\mathrm{s}^{-1}\right)$ (323K) increased from 6.8 to $10.42 \mathrm{~mol}$ $\mathrm{dm}^{-3}$ when $\mathrm{pH}=4.0, \mathrm{I}=0.3 \mathrm{~mol} \mathrm{dm}{ }^{-3}$ and $\left[\mathrm{Co}\right.$ (III) L] $=5.0 \times 10^{-3}$ mol dm "Table 1". The plot of $\mathrm{k}_{\mathrm{obs}}$ versus [GSH] "Fig. 4" was linear at different temperatures indicating first order dependence of rate on $[\mathrm{GSH}]$. Furthermore, the second order rate constant $\mathrm{k}_{2}{ }^{\prime}$ $\left(\mathrm{mol}^{-1} \mathrm{dm}^{3} \mathrm{~s}^{-1}\right)=\mathrm{k}_{\mathrm{obs}} /[\mathrm{GSH}]_{\mathrm{T}}$ almost remains constant. As the order of the reaction is one with respect to $[\mathrm{GSH}]_{\mathrm{T}}$, the order of the reaction is one with respect to [ $\mathrm{Co}(\mathrm{III}) \mathrm{L}]$. The rate law is therefore expressed as Rate $=\mathrm{k}_{\text {obs }}\left[\mathrm{Co}^{\mathrm{III}}-\mathrm{OH}\right]$

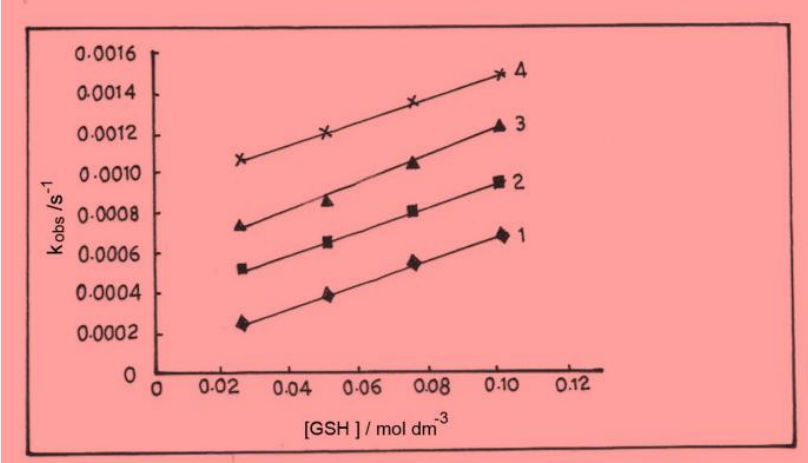

Fig. 4: Plot of $\mathrm{k}_{\mathrm{obs}}$ vs $[\mathrm{GSH}]$ at $\mathrm{I}=0.3 \mathrm{~mol} \mathrm{dm}^{-3}$, temp=318 $\mathrm{K}(1), 323 \mathrm{~K}$ (2), $328 \mathrm{~K}(3)$ and $333 \mathrm{~K}(4)$

\subsection{Effect of $\mathrm{pH}$ on reaction rate}

The effect of $\mathrm{pH}$ on reaction rate was studied varying $\mathrm{pH}=3.5$ to 5.0, [Co (III) L] $=5 \times 10^{-3} \mathrm{~mol} \mathrm{dm}^{-3}$, [GSH] $=2.5 \times 10^{-2} \mathrm{~mol} \mathrm{dm}^{-3}$ and $\mathrm{I}=0.3 \mathrm{~mol} \mathrm{dm}^{-3}$. The rate $10^{4} k_{\mathrm{obs}}(318 \mathrm{~K})$ increased from 2.48 to $6.8 \mathrm{~mol} \mathrm{dm}^{-3}$ as $\mathrm{pH}$ was increased from 3.5 to 5.0. This behavior was repeated for the entire $[\mathrm{GSH}]_{\mathrm{T}}$ range 0.025 to $0.1 \mathrm{~mol} \mathrm{dm}$ 3 . Plots of $\mathrm{k}_{\mathrm{obs}} /[\mathrm{GSH}]$ versus $\left[\mathrm{H}^{+}\right]$"Fig 5 " was a straight line indicating first order dependence of the rate on $\left[\mathrm{H}^{+}\right]$. The rate constants $\mathrm{k}_{1}$ and $\mathrm{k}_{2}$ were obtained from plots of $\mathrm{k}_{\mathrm{obs}} /$ [GSH] versus $\left[\mathrm{H}^{+}\right]$.

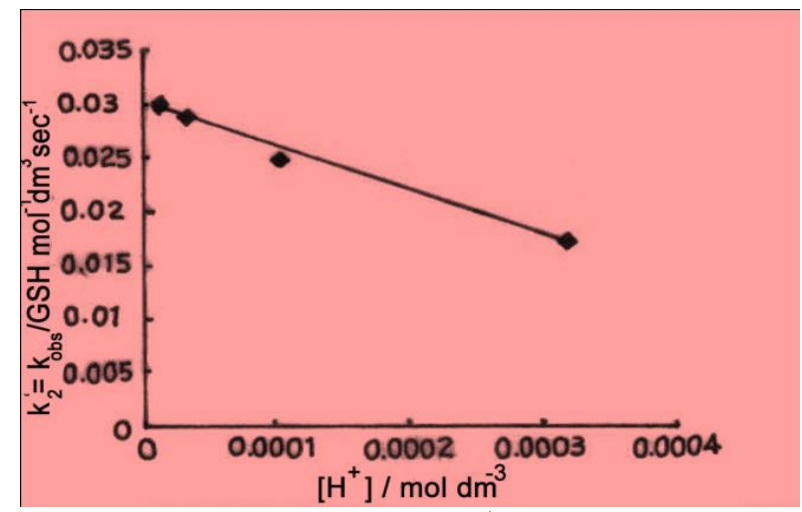

Fig. 5: Variation of $\mathrm{k}_{2}^{\prime}=\mathrm{k}_{\text {obs }} /[\mathrm{GSH}]$ vs $\left[\mathrm{H}^{+}\right]$at $328 \mathrm{~K},[\mathrm{GSH}]=0.05 \mathrm{~mol}$ $\mathrm{dm}^{-3}, \mathrm{I}=0.3 \mathrm{~mol} \mathrm{dm}^{-3}$

\subsection{Effect of temperature on reaction rate}

The rate of the reaction was studied varying the temperature $318 \mathrm{~K}$ to $333 \mathrm{~K}$, [Co (III) L] $=5 \times 10^{-3} \mathrm{~mol} \mathrm{dm}^{-3},[\mathrm{GSH}]_{\mathrm{T}}=2.5 \times 10^{-3} \mathrm{~mol}$ $\mathrm{dm}^{-3}, \mathrm{I}=0.3 \mathrm{~mol} \mathrm{dm}{ }^{-3}, \mathrm{pH}=3.5$. Pseudo-first order rate constant $\mathrm{k}_{\text {obs }}\left(\mathrm{s}^{-1}\right)$ were found to increase from $2.48 \times 10^{-4}$ to $10.71 \times 10^{-4}$ mol dm${ }^{-3}$ as temperature increased from $318 \mathrm{~K}$ to $333 \mathrm{~K}$, "Table 1 ".

Table 1: Pseudo-first order reaction rate constants of oxidation of GSH at different temperatures

\begin{tabular}{|c|c|c|c|c|c|c|}
\hline \multirow[t]{2}{*}{$\begin{array}{c}{[\mathrm{GSH}]} \\
\left(\mathrm{mol} \mathrm{dm}^{-3}\right)\end{array}$} & \multirow[t]{2}{*}{$\mathrm{pH}$} & \multirow[t]{2}{*}{$\begin{array}{c}10^{4}\left[\mathrm{H}^{+}\right] \\
\left(\mathrm{mol} \mathrm{dm}^{-3}\right)\end{array}$} & \multicolumn{4}{|c|}{$10^{4} \mathrm{k}_{\mathrm{obs}}\left(\mathrm{s}^{-1}\right)$} \\
\hline & & & $318 \mathrm{~K}$ & $323 \mathrm{~K}$ & $328 \mathrm{~K}$ & $333 \mathrm{~K}$ \\
\hline 0.025 & 3.5 & 3.160 & 2.48 & 5.20 & 7.55 & 10.71 \\
\hline 0.025 & 4.0 & 1.000 & 3.65 & 6.80 & 12.22 & 12.23 \\
\hline 0.025 & 4.5 & 0.316 & 6.53 & 8.67 & 11.08 & 13.95 \\
\hline 0.025 & 5.0 & 0.100 & 8.35 & 10.65 & 13.11 & 15.86 \\
\hline 0.05 & 3.5 & 3.160 & 3.97 & 6.58 & 8.74 & 12.04 \\
\hline 0.05 & 4.0 & 1.000 & 5.23 & 7.87 & 11.51 & 14.15 \\
\hline 0.05 & 4.5 & 0.316 & 8.10 & 10.30 & 13.45 & 15.81 \\
\hline 0.05 & 5.0 & 0.100 & 9.90 & 12.58 & 15.24 & 17.48 \\
\hline 0.075 & 3.5 & 3.160 & 5.58 & 8.06 & 10.54 & 13.55 \\
\hline 0.075 & 4.0 & 1.000 & 7.03 & 9.57 & 13.29 & 16.04 \\
\hline 0.075 & 4.5 & 0.316 & 9.43 & 12.17 & 14.66 & 17.61 \\
\hline 0.075 & 5.0 & 0.100 & 11.23 & 14.37 & 16.89 & 19.56 \\
\hline 0.10 & 3.5 & 3.160 & 6.80 & 9.32 & 12.33 & 14.82 \\
\hline 0.10 & 4.0 & 1.000 & 8.32 & 10.42 & 15.05 & 17.93 \\
\hline 0.10 & 4.5 & 0.316 & 11.15 & 13.58 & 16.00 & 19.44 \\
\hline 0.10 & 5.0 & 0.100 & 12.60 & 15.90 & 18.21 & 21.10 \\
\hline
\end{tabular}

\section{Discussion}

The oxidation reaction was occurred through two paths with the rate constants $\mathrm{k}_{1}$ and $\mathrm{k}_{2}$. Here $\mathrm{k}_{2}$ path was almost remains constant. So the activation parameters were determined from the electron transfer rate constants $k_{1}$. The values of $\Delta H_{1}^{\#}$ and $\Delta S_{1}{ }^{\#}$ were found to be $66.15 \pm 9.5 \mathrm{~kJ} \mathrm{~mol}^{-1}$ and $-77.77 \pm 29.2 \mathrm{JK}^{-1} \mathrm{~mol}^{-1}$ respectively. The moderate values of activation parameters favor the electron transfer reaction. The negative values of activation parameters suggested the formation of the ordered transition state. Since $\mathrm{pK}_{1}, \mathrm{pK}_{2}, \mathrm{pK}_{3}$ and $\mathrm{pK}_{4}$ of $\mathrm{GSH}$ are 2.05, 3.47, 8.63 and 9.52(Scheme 1), at higher concentration of the acid $0.03 \mathrm{~mol} \mathrm{dm}^{-3}$, the undissociated form of GSH will participate in the electron 
transfer reaction. The reaction sequence delineated below "Scheme 2" was consistent with the experimental data.

\section{Mechanism}

SCHEME - 1<smiles>NC(CCC(=O)N[C@@H](CS)C(=O)NCC(=O)O)CCC(=O)N[C@@H](CS)C(=O)NCC(=O)O</smiles><smiles>N[C@@H](CCC(=O)N[C@@H](CS)C(=O)NCC(=O)O)C(=O)O</smiles><smiles>N[C@@H](CCC(=O)N[C@@H](CS)C(=O)NCC(=O)O)C(=O)O</smiles><smiles>N[C@@H](CCC(=O)N[C@@H](CS)C(=O)NCC(=O)OCc1ccccc1)C(=O)O</smiles><smiles>N[C@@H](CCC(=O)N[C@@H](CS)C(=O)NCC(=O)O)C(=O)O</smiles><smiles>O=C(O)CNC(=O)[C@H](CS)NC(=O)CC[C@H](NC(=O)[O-])C(=O)O</smiles>

The above observation suggested the following mechanism as shown in "scheme 2". From the above reaction the rate law was derived as

SCHEME-2

Proposed mechanism of electron transfer reaction

$$
\begin{array}{cc}
\mathrm{Co}^{\mathrm{III}}-\mathrm{OH}_{2} & \stackrel{\mathrm{K}_{\mathrm{h}}}{\rightleftharpoons} \\
+ & \mathrm{Co}^{\mathrm{III}}-\mathrm{OH}+\mathrm{H}^{+} \\
\mathrm{GSH} & + \\
\downarrow k_{1} & \mathrm{GHS} \\
\mathrm{GS}^{\times}+\mathrm{Co} \text { (II) } & \mathrm{GS}^{\times}+\mathrm{Co}(\mathrm{II}) \\
2 \mathrm{GS}=\mathrm{GSSG} \text { (fast) }
\end{array}
$$

From the proposed mechanism, the rate law was derived as

$$
\mathrm{K}_{\mathrm{h}}=\frac{\mathrm{Co}^{\mathrm{III}}-\mathrm{OH}_{2}}{\mathrm{Co}^{\mathrm{III}}-\mathrm{OH}_{2}}
$$

Rate $=k_{1}[\mathrm{GSH}]\left[\mathrm{Co}^{\mathrm{III}}-\mathrm{OH}_{2}\right]_{\mathrm{e}}+k_{2}[\mathrm{GSH}]\left[\mathrm{Co}^{\mathrm{III}}-\mathrm{OH}\right]_{\mathrm{e}}$

$=k_{1}[\mathrm{GSH}]\left[\mathrm{Co}^{\mathrm{III}}-\mathrm{OH}_{2}\right]_{\mathrm{e}}+k_{2} K_{\mathrm{h}}\left[\mathrm{Co}^{\mathrm{III}}-\mathrm{OH}_{2}\right]_{\mathrm{e}}[\mathrm{GSH}] /\left[\mathrm{H}^{+}\right]$

$=[\mathrm{GSH}]\left[\mathrm{Co}^{\mathrm{III}}-\mathrm{OH}_{2}\right]_{\mathrm{e}}\left\{k_{1}\left[\mathrm{H}^{+}\right]+k_{2} K_{\mathrm{h}}\right\} /\left[\mathrm{H}^{+}\right]$

$\left[\mathrm{Co}^{\mathrm{III}}-\mathrm{OH}_{2}\right]_{\mathrm{T}}=\left[\mathrm{Co}^{\mathrm{III}}-\mathrm{OH}_{2}\right]_{\mathrm{e}}+\left[\mathrm{Co}^{\mathrm{III}}-\mathrm{OH}\right]_{\mathrm{e}}$

$=\left[\mathrm{Co}^{\mathrm{III}}-\mathrm{OH}_{2}\right]_{\mathrm{e}}+\left\{\left[\mathrm{Co}^{\mathrm{III}}-\mathrm{OH}_{2}\right] K_{h} /\left[\mathrm{H}^{+}\right]\right\}$

$=\left[\mathrm{Co}^{\mathrm{III}}-\mathrm{OH}_{2}\right]_{\mathrm{e}}\left\{\left[\mathrm{H}^{+}\right]+K_{h}\right\} /\left[\mathrm{H}^{+}\right]$

$\left[\mathrm{Co}^{\mathrm{III}}-\mathrm{OH}_{2}\right]_{\mathrm{e}}=\left\{\left[\mathrm{Co}^{\mathrm{III}}-\mathrm{OH}_{2}\right]_{\mathrm{T}}\left[\mathrm{H}^{+}\right]\right\} /\left\{\left[\mathrm{H}^{+}\right]+K_{h}\right\}$

Rate $=[\mathrm{GSH}]_{\mathrm{T}}\left[\mathrm{Co}^{\mathrm{III}}-\mathrm{OH}\right]_{\mathrm{T}}\left\{k_{1}\left[\mathrm{H}^{+}\right]+k_{2} K_{h}\right\} /\left\{\left[\mathrm{H}^{+}\right]+K_{h}\right\}$

Rate $=k_{\text {obs }}\left[\mathrm{Co}^{\mathrm{III}}-\mathrm{OH}\right]_{\mathrm{T}}$

Comparing (5) \& (6)

$k_{\mathrm{obs}}=[\mathrm{GSH}]_{\mathrm{T}}\left\{k_{1}\left[\mathrm{H}^{+}\right]+k_{2} K_{h}\right\} /\left\{\left[\mathrm{H}^{+}\right]+K_{h}\right\}$

$\frac{\mathrm{k}_{\mathrm{obs}}}{[\mathrm{GSH}]_{\mathrm{T}}}=\mathrm{k}_{2}^{\prime}=\frac{\left\{\mathrm{k}_{1}\left[\mathrm{H}^{+}\right]+\mathrm{k}_{2} \mathrm{~K}_{\mathrm{h}}\right\}}{\mathrm{k}_{2}^{\prime}\left\{\left[\mathrm{H}^{+}\right]+\mathrm{K}_{\mathrm{h}}\right\}}$

$k_{2}^{\prime}\left\{\left[\mathrm{H}^{+}\right]+\mathrm{k}_{\mathrm{h}}\right\}=\left\{k_{1}\left[\mathrm{H}^{+}\right]+k_{2} K_{h}\right\}$

Where $k_{2}^{\prime}=k_{\text {obs } /}[\mathrm{GSH}]_{\mathrm{T}}$

There exists two species of $\mathrm{Co}$ (III) as $\mathrm{Co}^{\mathrm{III}}-\mathrm{OH}_{2}$ and $\mathrm{Co}^{\mathrm{III}}-\mathrm{OH}$ in acid solution which was in equilibrium with each other. Both the species reacted with GSH through two paths with rates $\mathrm{k}_{1}$ and $\mathrm{k}_{2}$ respectively producing radicals $\mathrm{GS}^{\mathrm{x}}$ and Co (II). The $\mathrm{GS}^{\mathrm{x}}$ radicals dimerised rapidly forming GSSG.

From equation (8) the left hand side expression was plotted against $\left[\mathrm{H}^{+}\right]$. It showed a straight line with a positive slope. From the slope and intercept $k_{1}$ and $k_{2}$ were calculated. These values at four different temperatures $318-333 \mathrm{~K}$ were calculated and tabulated in "Table 2". It shows that $\mathrm{k}_{2}$ rate was much faster than $\mathrm{k}_{1}$.

The values of $\mathrm{k}_{1}$ (rate of oxidation of GSH by $\mathrm{Co}^{\mathrm{III}}-\mathrm{OH}_{2}$ species) varies with temperature whereas $\mathrm{k}_{2}$ (rate of oxidation of GSH by $\mathrm{Co}{ }^{\text {III }}-\mathrm{OH}$ species) remained almost constant and the activation parameters for the path $k_{1}$ were calculated and tabulated "Table

\begin{tabular}{|c|c|c|c|}
\hline Temp (K) & $\mathrm{pK}_{\mathrm{h}}$ & $\begin{array}{l}\mathrm{k}_{1} \\
\mathrm{~mol}^{-1} \mathrm{dm}^{3} \mathrm{~s}^{-1}\end{array}$ & $\begin{array}{l}\mathrm{k}_{2} \\
\mathrm{~mol}^{-1} \mathrm{dm}^{3} \mathrm{~s}^{-1}\end{array}$ \\
\hline 318 & 5.65 & 0.0073 & 0.127 \\
\hline 323 & 5.53 & 0.0128 & 0.112 \\
\hline 328 & 5.41 & 0.0176 & 0.105 \\
\hline \multirow[t]{3}{*}{333} & 5.30 & 0.0242 & 0.084 \\
\hline & $\Delta \mathrm{H}^{\#}=\quad(66.15$ & $\pm 9.15) \mathrm{kJmol}^{-1}$ & \\
\hline & $\Delta S^{\#}=\quad(-77.77$ & $\pm 29.2) \mathrm{JK}^{-1} \mathrm{~mol}^{-1}$ & \\
\hline
\end{tabular}
2 ". The activation parameters were determined from the electron transfer rate constants $k_{1}$

Table 2: Calculation of electron transfer rate constants and activation parameter

\section{Conclusion}

The oxidation reaction of GSH by Co (III) complex proceeded through two steps $\left(\mathrm{k}_{1}\right.$ and $\mathrm{k}_{2}$ ) producing free radical as $\mathrm{GS}^{\mathrm{x}}$ and Co (II) respectively. The free radical GS ${ }^{\mathrm{x}}$ dimerised to GSSG. Reduction at Co (III) center has been achieved due to generation of a radical at the bound ligand by the one equivalent oxidant. $\mathrm{k}_{2}$ path is much faster than $\mathrm{k}_{1}$ path. The activation parameters corresponding to $\mathrm{k}_{1}$ were evaluated, such as activation enthalpy $\left(\Delta \mathrm{H}^{\#}=66.15\right.$ $\left.\pm 9.5 \mathrm{~kJ} \mathrm{~mol}^{-1}\right)$ and activation entropy $\left(\Delta \mathrm{S}^{\#}=-77.77 \pm 29.2 \mathrm{JK}-1\right.$ mol-1). Moderate values of activation parameters favor the electron transfer process. Negative value of activation entropy corresponds to ordered transition state.

Since there was no experimental evidence of bridging of ligand between the oxidant and reductant, inner sphere mechanism was ruled out. The electron transfer mechanism between GSH and Co (III) complexes was expected to be outer sphere mechanism. 
Kinetics of oxidation of tripeptide (GSH) was compared with the kinetics of oxidation of one of its amino acid L - cysteine (Asemave et al. 2012) by Co (III) complex under similar conditions. It was concluded that the rate of electron transfer reaction of the tripeptide GSH is 40 times slower than amino acid.

\section{Acknowledgement}

The authors are thankful to H.O.D Chemistry, Utkal University, Vani Vihar, Bhubaneswar, Odisha, India for providing research facilities.

\section{References}

[1] Asemave K, Yiase SG, Adejo SO (2012) Kinetics and Mechanism of Substitution Reaction of Trans-Dichloro-bis-(Ethylenediammine) Cobalt (III) Chloride with Cysteine, Aspartic acid and Phenylalanine, International Journal of Science and Technology, 2(5):242-247.

[2] Basolo F and Pearson RG (1964) Mechanism of Inorganic Reaction, Wiley.

[3] Behm CA, Boreham PFL, Creaser II, Korybutdaszkiewicz B, Maddalena DJ, Sargeson AM \& Snowdown GM (1995) Novel Cationic Surfactants Derived From Metal Ion Cage Complexes: Potential Antiparasitic Agents, Australian Journal of Chemistry, 48(5):10091030

[4] Behm CA, Creaser I, Daszkiewicz B, Geue RJ, Sargeson AM \& Walker GW (1993) Novel cationic surfactants derived from metal ion cage complexes: potential anthelmintic agents, Journal of the Chemical Society, Chemical Communications, 24:1844-1846.

[5] Bernauer K, Ghizdavu S \& Verardo L (1999) Chiral metal complexes as probes in electron-transfer reactions involving metalloproteins, Coordination Chemistry Reviews, 190-192:357-369.

[6] Burel L, Mostafavi M, Murata S, Tachiya M (1999) Transient Effect in Fluorescence Quenching by Electron Transfer. 4. Long-Range Electron Transfer in a Nonpolar Solvent, The Journal of Physical Chemistry A, 103(30):5882-5888.

[7] Gerasimov OV, Lymar SV, Tsevetkov TM, Parmon VN(1988) Cobalt water oxidation catalyst immobilized on membranes of lipid vesicles, Reaction Kinetics and Catalysis Letters, 36(1):145-149

[8] Ghirlanda G, Scrimin P, Tecilla P \& Toffoletti A (1998) Amphiphilic Copper(II) Complexes Modeled after the Metal-Complexation Subunit of Bleomycin Antibiotics†', Langmuir, 14 (7):1646-1655.

[9] Karaman ME, Pashley RM \& Bolonkin NK (1995) Study of the Surface and Biological Activity of a Trivalent Cage Surfactant, Langmuir, $11(8): 2872-2880$.

[10]Kitson RE (1950) Simultaneous Spectrophotometric Determination of Cobalt, Copper, and Iron, Analytical Chemistry 22:664-667.

[11]Krisnamurty MJ (1972)Modified synthesis of trans-dichloro-bisethylenediamine cobalt(III) chloride, Journal of Inorganic and Nuclear Chemistry, 34:3915-3916

[12]Mohanty B, Behera J, Mohanty P, Acharya S, Patnaik AK \& Das SP(2011) Kinetics and mechanism of oxidation of L-cysteine and DLmethionine be morpholinium chlorochromate in aqueous acidic medium, Journal of Indian Chemical Society, 88(10):1561-1566.

[13]Nakamoto K (1997) Infrared and Raman Spectra of Inorg. And Coord. Compexes, 5th Edn, John Willey and Sons Inc. Publication.

[14]Osinsky S, Levitin I, Bubnovskaya L, Sigan A, Ganusevich I, Kovelskaya A, Valkovaskaya N, Campanella L \& Wardman P (2004) Selectivity of effects of redox-active cobalt(III) complexes on tumor tissue, Experimental Oncology, 26:140-144.

[15] Osinsky S, Levitin I, Sigan A, Bubnovskaya L, , Ganusevich I, Campanella L \& Wardman P (2003) Redox-active cobalt complexes as promising antitumor agents, Russian Chemical Bulletin, 52:26362645.

[16]Saik VO, Goun AA, Nanda J, Shirota K, Tavernier HL \& Fayer MD (2004) Photoinduced Intermolecular Electron Transfer in Liquid Solutions, The Journal of Physical Chemistry A, 108:6696-6703.

[17]Srinivasan S, Annaraj J \& Athappan PR (2005) Spectral and redox studies on mixed ligand complexes of cobalt(III) phenanthroline/bipyridyl and benzoylhydrazones, their DNA binding and antimicrobial activity, Journal of Inorganic Biochemistry, 99:876882.

[18] Tavernier HL, Barzykin AV, Tachiya M \& Fayer MD, (1998)Solvent Reorganization Energy and Free Energy Change for Donor/Acceptor Electron Transfer at Micelle Surfaces: Theory and Experiment, The Journal of Physical Chemistry B, 102 (31):6078-6088
[19] Weidemaier K, Tavernier HL \& Fayer MD (1997) Photoinduced Electron Transfer on the Surfaces of Micelles, The Journal of Physical Chemistry B, 101:9352-9361.

[20]Wolak M, Stochel G, Eldik Rv (2003) Mechanistic Studies on the Interaction of Reduced Cobalamin (Vitamin B12r) with Nitroprusside, Journal of the American Chemical Society, 125:1334-1351. 